National Tax Journal, June 2012, 65 (2), XXX-XXX

\title{
THE MIRRLEES REVIEW: A U.S. PERSPECTIVE
}

\begin{abstract}
Alan J. Auerbach
The recently completed Mirrlees Review focuses on reforming the U.K. tax system. It represents an unusual blend of "best practice" application of economic theory and evidence to realistic policy design; it lays out policy proposals with sufficient justification and specificity that they go well beyond a statement of principles for reform. This paper examines the lessons that can be drawn from the analysis and conclusions of the Mirrlees Review, which have broad value especially for advanced countries like the United States that share many of the characteristics of the U.K. and face many of the same issues of tax policy design.
\end{abstract}

Keywords: international taxation, tax reform, inequality, consumption taxation, Mirrlees Review

JEL Codes: H25, K34

Alan J. Auerbach: Department of Economics and School of Law, University of California, Berkeley, CA, USA (auerbach@econ.berkeley.edu) 


\section{INTRODUCTION}

The recently completed Mirrlees Review was a considerable undertaking, resulting in two thick volumes. The first volume, Dimensions of Tax Design (Mirrlees et al., 2010), is a compilation of specially commissioned chapters dealing with different aspects of the tax system, and also includes the comments of discussants from the 2007 conference at which these chapters were originally presented. The second volume, Tax by Design (Mirrlees et al., 2011), was written by the project's editors and sets out the conclusions of the Mirrlees Review, including concrete proposals for reform. Although the Mirrlees Review formally focused on the UK tax system, its analysis and conclusions have much broader value, especially for advanced countries like the United States that have many of the same characteristics and face many of the same issues of tax policy design.

Like the Meade Committee's review of the UK tax system undertaken over three decades ago (Institute for Fiscal Studies, 1978), the Mirrlees Review, also done under the aegis of the Institute for Fiscal Studies, aimed to evaluate the UK tax system and consider potential reforms in light of the most recent economic developments and findings in the literature. The publication

this time of a first volume — laying out these economic developments and findings — provides a clearer backdrop for the conclusions and policy recommendations that the second volume offers. In many cases, one can trace the ultimate recommendations in the second volume to analysis provided in the first. In other cases, the editors have come to different conclusions than the first volume's chapter authors, while providing some rationale for this difference in direction.

Even with the recent publication date, there have already been several evaluations of the Mirrlees Review, most notably in a special issue (September, 2011) of Fiscal Studies devoted to the topic. This special issue included an overview by the editors themselves as well as several 
perspectives on different elements of the Review by leading scholars. With these and other contributions already available, I will not try to offer an overall assessment of the Mirrlees Review, although it clearly must be considered a major compilation and synthesis of current thinking on what constitutes good tax policy. Instead, I will be selective and focus on several key questions with which the Review deals, with the aim of drawing implications for U.S. tax policy, including what one may learn from differences between the UK and U.S. economic and policy environments.

In focusing on implications for U.S. tax policy, I will not cover such important topics in the Review as the reform of the Value Added Tax (VAT), since the United States remains essentially the only developed country that does not impose one. There is some irony to this “U.S. exceptionalism," as it would be easier, in administrative terms, for the United States to adopt a clean VAT; it does not face the restrictions the United Kingdom confronts as a result of membership in the European Union. ${ }^{1}$ Also, in the United States, where tax collections at the subnational level are much more important than in the United Kingdom, adoption of a VAT at the federal level could facilitate reform of state-level taxation, through the adoption of harmonized state-level VATs that would represent a distinct improvement over the existing antiquated and distortionary retail sales taxes. This is a model that has worked well in Canada over the past two decades. ${ }^{2}$ I will also not discuss environmental taxation, to which the Review devotes three chapters. This is an important area where current U.S. policy clearly needs attention, but it is somewhat distinct from the income tax issues considered below.

\footnotetext{
${ }^{1}$ For example, while an important reform of the existing VAT would be to extend it, in some manner, to financial services, "The exemption of financial services, like other VAT exemptions, is mandated by EU law. It may therefore be that reform must be pursued at an EU level ..." (Mirrlees et al., 2011, p. 214).

${ }^{2}$ See Auerbach (2011) for further discussion of this issue.
} 


\section{SIMPLICITY}

An overarching principle adopted by the Review is that tax systems should be as simple and transparent as possible. For example, in criticizing the haphazard schedule of effective marginal tax rates that apply at different income levels for a particular set of taxpayer attributes, the Review argues,

A basic requirement for any system of taxing earnings is that the rate schedule should be transparent. The UK tax system is far from meeting that requirement, and reforming income tax itself would be a good place to start. The biggest offender is the taperingaway of personal allowances as income rises ... If setting these effective tax rates is the objective, then it should be explicit in the marginal rate schedule, not described opaquely as a phased withdrawal of the personal allowance: this peculiar mechanism serves no purpose except to obscure what the tax system is actually doing (Mirrlees et al., 2011, p. 105).

Aside from general confusion, the Review sees the cost of such an indirect approach as a hodgepodge of unintended interactions among provisions that can result in gratuitous distortions and efficiency losses. The Review suggests that, while the hypothetically optimal tax schedule might be complicated, it is likely that it can be reasonably well approximated by a relatively simple one.

One might add that interest-group politics make it unlikely that deviations from simple and straightforward tax rules will be dictated by optimal tax considerations in any case; complexity and the common use of special tax provisions and regimes may contribute to unproductive lobbying and other rent-seeking activity as well. Thus, the Review also sees merit in maintaining neutrality in the treatment of similar activities, whether through the earning of income or the consumption of different goods and services, unless there is a compelling case to deviate.

If tax schedule complexity is an issue in the UK tax system, then it is certainly one in the U.S. system as well. We are currently experiencing a momentary reprieve from the phase-outs of 
itemized deductions and personal exemptions (commonly referred to as the Pease and PEP provisions) under the personal income tax, which were introduced as part of the 1990 budget deal between President George H.W. Bush and Congress to mask increases in marginal tax rates, but their return in 2013 is scheduled under both current law and (starting at a higher income threshold) President Obama's most recent budget proposal. We struggle to pass annual legislation to limit the reach (due to its lack of indexing for inflation) of the alternative minimum tax (AMT) on individuals, which when first introduced four decades ago (in response to outrage at the large number of wealthy individuals paying no income tax) impacted only around 20,000 taxpayers per year, but in recent years has affected roughly 4 million taxpayers (Burman et al., 2008).

In spite of this annual legislative headache caused by the AMT, its apparent allure in policy circles appears unabated, and we now confront at least two new minimum tax proposals — the so-called "Buffett rule" that would impose a minimum average tax rate on the incomes of high income individuals, and a minimum tax on the overseas income of U.S. multinational corporations. $^{3}$

There are a variety of possible rationales for reliance on phase-outs and minimum taxes rather than more direct and transparent provisions based on underlying objectives, but none of these arguments are especially compelling in light of the complexity and distortions that such provisions typically introduce. ${ }^{4}$

\footnotetext{
${ }^{3}$ The Buffett rule was proposed in February 2012 in the Administration's budget for fiscal year 2013 (U.S. Office of Management and Budget, 2012); the tax on multinationals was proposed shortly thereafter as part of a package of corporate tax changes (U.S. Department of the Treasury, 2012). The exact details of both proposals are as yet unclear.

${ }^{4}$ For further discussion, see Auerbach (2010a).
} 


\section{CAPITAL INCOME TAXATION}

One of the Meade Committee's most important contributions was its discussion of broadbased consumption taxation — how it might be implemented and what its attractions are in relation to the traditional income tax. In the 1960s, and indeed well into the 1970 s, the standard objective of tax policy design, well represented, for example, in the work of Pechman (1987), was the achievement of a broad-based, Haig-Simons income tax. Consumption taxes existed, of course, notably in Europe in the form of the VAT, but these arose as improvements that eliminated the cascading effects of turnover taxes, and as indirect taxes were appropriately not viewed as effective vehicles for progressive taxation.

Arguments for an individual expenditure tax have existed for decades, of course, including the important contributions of Fisher (1939) and Kaldor (1955), who argued, respectively, that income taxes unfairly impose double taxation of saving and that consumption taxes can serve more effectively to impose tax burdens on accumulated wealth. Though these arguments were recognized, a serious move toward viewing the expenditure tax as a viable alternative did not begin until two important developments in the 1970s - the theoretical contributions, most notably by Atkinson and Stiglitz (1976), that suggested the desirability of avoiding capital income taxes, and the Meade Committee report (along with a contemporaneous document by the U.S. Department of the Treasury (1977)), that laid out how direct expenditure taxes might actually be implemented. In the years since the Meade report, there have been many additional contributions adding to both the theoretical support for progressive consumption taxes and the knowledge of how such taxes might be imposed. ${ }^{5}$

As the possibility of adopting a broad-based consumption tax has been taken more seriously, however, the literature has also come to include contributions questioning the benefits

\footnotetext{
${ }^{5}$ These developments are reviewed in Auerbach (2008).
} 
of adoption in a number of ways. These include arguments that generous transition relief — as might be politically necessary to accomplish the shift — make the consumption tax far less attractive (Auerbach, 1996), that the distortions of capital income taxes may only relate to the risk-free rate and therefore may be small (Warren, 1996), that market imperfections might make capital income taxation more attractive (Aiyagari, 1995), that capital income might be an indicator of ability, even given labor income (Saez, 2002), and that taxing the returns to saving may serve as a substitute for age-based labor income taxation (Erosa and Gervais, 2002) or — by discouraging private saving — can help implement progressive labor income taxes by making it more painful for those with high ability not to work (Golosov et al., 2003). Further, various recent results from the field of behavioral economics suggest that institutional factors may matter more than the tax base itself, and that a broad-based consumption tax need not promote saving more effectively than a series of specific tax-favored savings-promotion schemes.

This enrichment of our thinking about possible roles for at least some capital income taxation is very nicely summarized in the paper by Banks and Diamond (2010) in the Mirrlees Review's first volume, which argues that the case for full elimination of capital income taxation is not at all obvious in light of the many possible roles that capital income taxes might play. Even with this nuanced view, of course, we have moved quite far from thinking it natural that capital and labor income should be taxed according to the same schedule, even if this movement is not yet fully reflected in public U.S. discourse, which, in spite of the existence of favorable tax rates on dividends and capital gains, still largely adopts the view that "income is income," especially when contemplating the low average income tax rates paid by high-income individuals.

In the end, though, the policy recommendations put forward in the Mirrlees Review's second volume adopt a simpler approach than the Banks-Diamond analysis might suggest: 
All of these arguments are well founded in economic theory. They justify levying some tax on the normal return to capital, though not necessarily at full labor income tax rates, as in a comprehensive income tax. However, there are several reasons to be cautious in applying these arguments immediately to policy (Mirrlees et al., 2011, p. 313).

These reasons for caution are basically that it is hard to know what the capital income tax rate should be, and not clear that having a small positive capital income tax rate provides sufficient benefit to justify the complexity of implementation, particularly given the importance that the Review's editors place on having a simple and logical tax system. Thus, perhaps somewhat surprisingly in light of recent developments in the literature, the Review comes down against taxing the normal return to capital, rather than, for example, opting for a low but positive rate of tax, as under the dual income tax approaches adopted in recent years in Norway and elsewhere (Sørensen, 1998). Having decided not to tax the normal returns to capital, the Review then devotes much of its attention in this area to alternative methods of achieving this policy objective.

In laying out how to exempt the normal return to capital, the Mirrlees Review draws on the Meade Committee's analysis, pointing out that one can achieve the result using either a TEE approach (full Tax on initial saving, Exempt from tax on inside build-up, Exempt from tax on withdrawal) or an EET approach (exempt from tax until withdrawal, at which time full tax is imposed), also sometimes known, respectively, as wage-tax and consumption-tax treatment of saving. The relative strengths of the two approaches have been analyzed extensively over the years, with the conclusion that the EET method has the ability to capture supernormal returns to saving (possibly arising from the existence of rents, as compensation for risk-taking, or as disguised returns to labor), while the TEE approach is less susceptible to changes in tax rates 
over time, which under the EET approach (where the tax liability effectively is deferred with interest to a later date) can induce large swings in the incentive to save. ${ }^{6}$

In addition to these relative merits, the U.S. observer will be familiar with another "benefit" of the TEE approach — that it allows the government to collect revenue earlier (but, again, not higher in present value when the tax rate is constant), thus making the government's fiscal position appear stronger when measured using a finite-term budget window. This was probably the prime factor driving development of the Roth IRA and related saving vehicles, such as the Roth 401(k), and was certainly the main motivation for the relaxation of restrictions for switching balances from traditional EET accounts to Roth (i.e., TEE) accounts (and thereby accelerating tax payments), which because of additional tax incentives actually sacrifice revenue in present value. ${ }^{7}$

To the TEE and EET approaches, the Mirrlees Review adds a third, the TtE or Rate of Return Allowance (RRA) method, which partially avoids the timing misalignment of the EET approach while still taxing supernormal returns, unlike the TEE approach. The RRA method, like the current income tax system (which for taxable capital earnings one can characterize as TTE), taxes the annual returns to capital as they occur, but in this case only partially, allowing a deduction for the normal rate of return and thus leaving only supernormal returns in the tax base. Because the intent is to tax all returns above the risk-free rate of return to capital, the Review's approach would use a government bond yield to approximate the normal rate of return. ${ }^{8}$

\footnotetext{
${ }^{6}$ Another disadvantage of the EET approach, present in both the U.S. and UK systems with respect to the tax treatment of pensions, is that it makes the taxation of bequests more complicated, for the transmission of wealth can trigger both income and wealth transfer taxes, which must then be coordinated.

${ }^{7}$ The Tax Increase Prevention and Reconciliation Act of 2005 eliminated (starting in 2010) the income ceiling that had prevented some taxpayers from transferring balances from EET accounts into Roth IRAs and, for 2010, also gave taxpayers the election to defer (without interest) tax payments on transferred balances until 2011 and 2012. ${ }^{8}$ Like the TEE and EET approaches, the TtE approach automatically corrects the tax base for the effects of inflation, in this case through the use of a nominal interest rate, which includes an inflation premium, to measure the normal rate of return.
} 
Many readers will be familiar with the TtE approach as the same one adopted under the Allowance for Corporate Equity (ACE), another IFS (Institute for Fiscal Studies Capital Taxes Group, 1991) contribution to tax policy, which is also resurrected by the Mirrlees Review in its proposed corporate tax reform (on which there is more discussion below). While the $\mathrm{TtE}$ approach has advantages relative to both the TEE and EET approaches, it also has one particular disadvantage, as it is more complicated than either of the other two approaches, neither of which requires the specification of the normal rate of return or taxpayers to keep track of asset bases. In this circumstance, though, the Review deems the added complexity to be worth accepting. One may also note that the TtE approach most closely resembles the existing system, and therefore may be deemed a less radical deviation from the status quo. Indeed, the Review suggests that transition to the TtE system would be easier than one to an EET system.

Another transition issue not explicitly discussed in the Review is the treatment of "old capital." As is well-known (e.g., Auerbach and Kotlikoff, 1987), an immediate switch to TEE taxation provides windfalls to old capital by relieving it of future income tax payments, while transition to an EET system imposes a levy on old capital by taxing all withdrawals from accounts rather than just income. A switch to the TtE system would fall somewhere in between, making it in some ways less attractive than the EET approach in terms of both efficiency and progressivity, but perhaps also easier to adopt without the administrative challenges of identifying and segregating existing assets on the one hand and delivering transition relief on the other. The difficulty in designing provisions under one of the few serious attempts to adopt an expenditure (i.e., EET) tax in the United States, the "USA Tax" in the 1990s, ${ }^{9}$ suggests that this is an important consideration.

\footnotetext{
${ }^{9}$ See Warren (1995) for discussion of the Unlimited Savings Allowance (USA) Tax.
} 
Given that each of the three of the approaches to exempting the normal return to saving has arguments in its favor and against it, the Mirrlees Review adopts not one, but all three, depending on particular circumstances. For example, pension saving would be accorded EET treatment, largely because that is how it is treated now; bank accounts would fall under the TEE regime, to avoid tax-free provision to customers of the services embedded in reduced rates of return; and other household saving would generally have the option of using the TtE approach for balances above some threshold amount (for which TEE would be allowed). ${ }^{10}$

In limiting the ability of households to choose between the EET approach and one of the other approaches, the Review explicitly acknowledges that it is reducing the ability of taxpayers to alter the timing (but not the present values) of their tax bases, which, as the Meade report noted, would be of value as an averaging device under the progressive rate structure envisioned by the Review. Two defenses are offered for this restriction. One is that smoothing would blunt the effectiveness of the government's ability to impose time-varying tax rates on individuals. For example, if the government wished to impose higher marginal tax rates on older individuals (say, because of a lower labor-supply responsiveness), then allowing taxpayers to transfer EET balances into TEE accounts (as in the switch from a traditional IRA to a Roth IRA) could undo this policy. The argument is that the cost of reducing the individual benefits of smoothing out idiosyncratic shocks is outweighed by the benefits of reduced overall tax avoidance.

\footnotetext{
${ }^{10}$ Capital assets subject to $\mathrm{TtE}$ treatment, such as corporate shares, would still presumably be taxed on a realization basis. That is, only realized returns above the tax-free threshold would be subject to tax in any given year. With the individual's tax rate constant over time, this treatment would not distort the realization decision, because a higher tax base in one year resulting from the realization would generate a higher tax-free threshold on reinvested funds in subsequent years, the two tax-base effects cancelling out in present value. However, an expected change in the individual's tax rate (because of a change in law or individual circumstances) would impose either a net penalty on realization (if the tax rate is expected to fall) or a net benefit (if the tax rate is expected to rise). As discussed further below in respect to the taxation of wealth transfers, one particular case in which a fall in the tax rate could be expected would be at death. That is, the lock-in effect of the current system due to basis step-up at death would still be present to some extent. This particular effect would not arise under the TEE approach, where realization would have no tax consequences, or the EET approach, where the sale of one asset and purchase of another of equal value would also have no net effect on current or future tax liabilities.
} 
A second argument against smoothing is equity-based:

As far as full smoothing is concerned, the main issue is one of equity. It seems likely that only the unusually well-informed, and relatively well-off, would take full advantage (Mirrlees et al., 2011, p. 316).

Even though the nature of taxpayer decision-making has received much more attention in recent years, this statement comes across as rather paternalistic in relation to the general tone of the report. One might wish for a little more detail concerning the supposed sources of differential smoothing. If, for example, those who do not smooth are simply inattentive about marginal tax rates, then there might be an efficiency argument in favor of allowing those who are attentive to smooth. On the other hand, the story likely would be different if those who do not smooth are simply liquidity constrained (e.g., they don't have the funds to prepay taxes, as would be required by putting funds into a TEE account rather than an EET account).

Another argument against smoothing, not mentioned in the report, is that the choice adds complexity to the tax system and its enforcement, in particular to prevent individuals from manipulating the composition of assets and placing low-yield assets in EET accounts and highyield assets in TEE accounts. Also, as a practical matter, if the government is likely to need to raise revenue in the future through an increase in marginal tax rates, it might not wish to allow taxpayers to avoid this rate increase through shifts in balances from EET to TEE accounts, as may now be occurring in the United States.

In the end, while taking a position against full smoothing, the Review deems the issue of how much flexibility to allow in the choice of tax treatment to be one that might be revisited in the future once the functioning of the system has been observed. 


\section{WEALTH TRANSFER TAXES}

Like the United States, the United Kingdom has experienced an increase in income inequality in recent decades. From 1980-2000, the ratio of male wages in the $90^{\text {th }}$ and $10^{\text {th }}$ percentiles in each country grew by nearly a third. While other OECD countries also experienced growth in inequality over the same period, these two countries were among the leaders, a result consistent with other studies (e.g., Saez, 2006). What is the appropriate response of the tax system to such changes?

There are two obvious arguments in favor of increasing the progressivity of the tax burden in response to these developments. First, with a thicker upper tail of the income distribution, the equity-efficiency trade-off associated with increasing marginal tax rates on highincome individuals becomes more favorable, for given taxable income elasticities since more revenue is obtained for a given increase in the marginal tax rate. Second, for any standard social welfare function, greater inequality increases the value of a dollar of redistribution, holding constant its efficiency cost. But what is the best way to achieve tax progressivity? The base and rate structure of the income tax are natural places to look, but even more obvious is the system of wealth transfer taxation, which traditionally focuses on the wealth of individuals near the top of the wealth and lifetime income distributions.

The United Kingdom imposes what is officially called an inheritance tax, although it works effectively as an estate tax, like the one that exists (at least for the moment) in the United States. Aside from the trivial distinction regarding statutory incidence (the inheritance tax is paid by the recipient, the estate tax by the donor), the two taxes typically will differ in the extent to which their assessments depend on the economic circumstances of the recipient. While the U.S. estate tax rate does vary between charitable recipients (for whom the tax rate is zero) and others, 
inheritance tax rates could more easily vary according to the recipient's income, a feature that has motivated proposals to switch from estate taxation to inheritance taxation in the United States (Batchelder, 2007). However, this is not a feature of the UK inheritance tax, which applies at a rate of 40 percent over a tax-free threshold, very much resembling the structure of the U.S. estate tax. Indeed, the Review sees this lack of dependence on the circumstances of recipients as an unfortunate limitation of the current UK system.

Like the U.S. estate tax, the UK inheritance tax affects only a few percent of decedents, accounts for a small share of total revenues, and is extremely unpopular:

The main effort to tax wealth transfers in the UK is inheritance tax, which is, so far as we know, the only tax in the UK that around half the population seriously believes should be abolished altogether, with most of the rest wanting significant cuts (Mirrlees et al., 2011, p. 358).

Standard economic analysis has failed to identify a coherent reason for this apparently universal lack of popularity, given the weakness (because of the small numbers involved) of arguments relating to family farms and businesses, particularly in light of the fact that special provisions that relieve tax already exist in such cases.

The UK inheritance tax exempts transfers between spouses (or civil partners) and allows a transfer of the first spouse's unused taxpaying threshold, thus allowing a double threshold for intergenerational transfers, much like the treatment in the United States since 1981. But this provision, which effectively treats spouses as a single unit, fits more naturally within the U.S. context, where spouses typically file jointly under the income tax, than in the UK context, where spouses file as individuals, and the Review sees it as an illogical feature. Indeed, the tension between provisions that (like this one) effectively treat spouses as members of an integrated family unit and others that are individual-based comes up elsewhere in the Review, as discussed below in regard to the tax treatment of the family. 
One interesting difference between the U.S. and UK systems of wealth transfer taxation, which the Review sees as an important area for reform, is the treatment of inter vivos gifts. The U.S. system integrates estate and gift taxation, to reduce the ability of individuals to avoid estate taxation simply by making lifetime gifts. While the U.S. system does not eliminate the tax advantage of inter vivos gifts, ${ }^{11}$ the gift tax is understood to be a key component of the wealth transfer tax system. Indeed, when the U.S. estate tax temporarily disappeared in 2010 as a consequence of the 2001 Bush tax cuts, gift taxes did not; since taxpayers could reasonably have expected the estate tax to reappear in some form at a later date, a temporary repeal of the gift tax would have opened the escape hatch to a much larger group of tax avoiders than those who had the "good luck" of dying in 2010.

Even with gift taxation in place the U.S. estate tax is criticized as being relatively susceptible to tax planning and avoidance. But the UK system does not tax gifts at all, unless they occur within seven years of the donor's death. Even in such cases, the tax is at a lower rate the further from death the gift is made (Mirrlees et al., 2011, p. 359), so the aim appears to be to tax gifts "in anticipation of death," a concept familiar in the U.S. context but one that appears at odds with the fact that death can be anticipated regardless of one's life expectancy.

As the Review notes, "the biggest barrier to the effective operation of inheritance tax is the failure to tax inter vivos transfers" (Mirrlees et al., 2011, p. 363). It is interesting that taxation of such transfers has been viewed as unworkable in the United Kingdom, given that it works, at

\footnotetext{
${ }^{11}$ Such gifts enjoy at least four advantages. First, direct payments for items such as education are ignored. Second, annual gifts up to an indexed ceiling (currently $\$ 13,000$ per beneficiary and giver) are also completely ignored for tax purposes. Third, although an integrated lifetime exclusion applies to estates and remaining gifts over the threshold, gifts are counted on a tax exclusive basis, but estates are counted on a tax inclusive basis. Finally, gifts occur earlier than bequests, so that the earnings in the years between the time of the gift and the time of death are excluded from the wealth transfer tax base.
} 
least to some extent, in the United States, which has no apparent advantages with respect to its tax administration capacity or reporting requirements.

Finally, the UK system, like the U.S. system, forgives capital gains tax (CGT) for appreciated assets transferred at death, through a step-up in asset bases. As in the United States, the spurious double-taxation argument appears, and the Review can only lament that "Forgiveness of CGT at death looks like another half-hearted reluctance to adopt a principled position. But it is highly distortionary" (Mirrlees et al., 2011, p. 365). As already noted above, this problem would still exist to some extent under a reformed TtE system of capital income taxation, if that system were based on realization rather than accrual and returns exceed the amounts deductible under the RRA calculation.

In summary, it seems pretty clear, unfortunately, that the UK tax system and the Review's evaluation of it do not reveal the secrets of effective wealth transfer taxation, including how to overcome both political and administrative barriers.

\section{CORPORATE TAXATION}

How to tax corporations is a complex question, and one that has become more complex since the Meade Report. Three main issues stand out as having made the issue more challenging during the past few decades. First, the growth in importance of multinational enterprises has made the treatment of international capital flows an issue of first-order importance. Second, financial innovation has increased the ability of corporations to exploit differences in the tax treatment of debt and equity. Finally, at least in the United States, the corporate-noncorporate boundary has shifted, with a much greater share of business activity and income escaping the traditional corporate form and the corporate income tax. ${ }^{12}$

\footnotetext{
${ }^{12}$ In 1980, C corporations accounted for 80 percent of U.S. business income, while partnerships, sole proprietorships, limited liability companies, and S corporations made up the remainder. By 2007, the C-corporation
} 
In keeping with the complexity of the issue, the Review's first volume contains two papers that touch on corporate taxation (Auerbach, Devereux, and Simpson, 2010; Griffith, Hines, and Sørensen, 2010) plus one on the taxation of small business (Crawford and Freedman, 2010), and the second volume also devotes three chapters to these topics.

As mentioned above, the Review opts for the TtE approach to corporate-level taxation of equity income, through the ACE system that provides a deduction for the normal rate of return to equity. In addition to the advantage over the cash-flow tax with respect to timing and tax rate changes, adopting this approach at the corporate level involves a reform that is less radical in appearance, maintaining the current deductions for interest expense and depreciation. As is now well known, the ACE system, which is applied to the undepreciated bases of assets less debt, makes any pattern of depreciation allowances have the same present value as immediate expensing, thus rendering the particular depreciation schedule relatively unimportant. ${ }^{13}$ Also, the treatment of financial institutions involves a simple change in the tax treatment of their small equity base, and therefore is much less of a challenge than under a cash-flow tax, for which the main question has been how to mesh two separate tax bases (to use the terminology introduced by the Meade Report): the standard R base (which ignores financial transactions) that would apply for nonfinancial companies and the $\mathrm{R}+\mathrm{F}$ base (which also includes financial transactions) that would be more logical for financial companies (Auerbach, Devereux, and Simpson, 2010; Mirrlees et al., 2011).

\footnotetext{
income share had fallen to 53 percent, with the fastest relative growth experienced by $\mathrm{S}$ corporations - corporations from a legal perspective that are taxed as pass-through entities, with their income attributed directly to shareholders and taxed only at the shareholder level. The income share of S corporations rose from 1 percent in 1980 to 14 percent in 2007 (President's Economic Recovery Advisory Board, 2010).

${ }^{13}$ The pattern still matters somewhat, because it determines the timing of taxes and hence the sensitivity of decisions to tax rate changes and the likelihood that companies with high rates of investment will experience net operating losses.
} 
With the normal returns to investment exempt at both the corporate and investor levels, there is a less obvious need for further integration of corporate and individual taxes, in contrast to the case of the traditional income tax, where the double taxation of normal equity returns is an issue. Moreover, the treatment of unincorporated small businesses, which the Review tackles in Chapter 19, can also follow the same TtE approach as a component of individual investment, in which context the approach has a significant benefit (shared by the EET approach) of eliminating incentives for changing the characterization of income between labor and capital (since the same rate schedule applies).

Note that there would still be at least a superficial distinction in the treatment of returns in the corporate and noncorporate sectors, with corporate supernormal returns being taxed twice and noncorporate returns taxed only once. ${ }^{14}$ But the Review is careful to take this into account in setting the rate schedule, calling for a lower tax rate on investor-level returns on corporate equity (above the normal rate of return) than on earnings from ownership of unincorporated passthrough entities not subject to the corporate level tax, so that the aggregate tax rate on supernormal returns is the same for corporate and noncorporate entities. However, there could still be an incentive for corporate businesses to shift to another country, if the supernormal returns are rents associated with some unmeasured company-level attributes. The question of potential international mobility raises the broader issue of how the returns to multinational enterprises should be taxed, which the Review recognizes as a very challenging one.

As the Review notes, there are basically three possible choices for determining the location of the tax base in an international context: residence (of the taxpayer), source (i.e.,

\footnotetext{
${ }^{14}$ The timing of the taxes on supernormal returns at the two levels might differ. For example, if the supernormal returns are due to rents earned by the corporation, then these will be capitalized into share values and thereafter investors will not earn supernormal returns on their positions. However, the rents will still be subject to tax at the individual level to the extent that the initial rise in share values due to the appearance of rents is subject to tax.
} 
where income is earned), and destination (i.e., where purchased goods and services are used). Unless a company produces and sells in the jurisdiction where it resides, these three tax bases will be different. To a large extent, existing tax systems adopt each of the three approaches depending on the type of tax, as they use the destination basis for the VAT, the residence basis for the individual income tax and, to an increasing extent, the source basis for the corporate income tax. But these associations between tax and tax base determination are not inherent, nor are they in practice exact. As a notable example, the United States corporate income tax is still applied (at least formally) on a residence basis, with the residence being that of the corporation. While shifts in the relative importance of the tax bases in raising revenue have mechanically affected the reliance on the different methods of determining the location of the tax base, there has also been a shift within corporate taxation toward the use of the source basis. With the recent adoption of this approach by the United Kingdom and Japan, the United States now stands alone among the world's leading economies still adhering, at least in some fashion, to the residence principle of corporate taxation.

Of course, the U.S. system is not close to being a "pure" residence-based tax, which would tax on accrual and on a single schedule the worldwide income of resident corporations. It allows deferral of tax on unrepatriated corporate earnings of foreign subsidiaries and permits a foreign tax credit, but only up to the U.S. rate of tax, on repatriated earnings; both features push the tax system and its effects in the direction of a source-based tax, where the effective tax rate on foreign earnings is the foreign tax rate. The current U.S. policy debate centers on whether to move further in the direction of source-based taxation or to attempt to impose stronger elements of residence-based taxation, such as more current taxation of foreign-source earnings. 
The debate between proponents of source-based and residence-based corporate taxation is vexing, because neither approach has a strong logical basis. If a country's corporations could be viewed as conduits for the saving of its individual residents, then the reasonably compelling argument for applying residence-based income taxation at the individual level would extend to the design of corporate income taxes. Perhaps this was a reasonable approximation several decades ago, but it is less so now for two reasons. First, corporations can be funded from abroad, and international portfolio finance has increased in importance over time. ${ }^{15}$ Thus, taxes on resident corporations would not be similar in character to taxes on the savings of domestic residents, and could limit the ability of corporations to compete internationally for capital. Second, corporate residence is not immutable. Corporations, like capital, are internationally mobile, so the residence decision itself is subject to distortion by taxation. Therefore, the logic of applying residence-based taxation at the corporate level is far less clear than it is at the individual level, where residence is more fixed. The more corporations are internationally mobile and compete worldwide for capital, the less meaning attaches to corporate residence and the less desirable is residence-based corporate taxation.

Source-based corporate taxation, on the other hand, confronts its own difficulties. These would be reduced under the Review's proposed use of the ACE system to exclude normal returns to capital from the tax base, as incentives to shift capital abroad to avoid tax would be reduced. As the Review observes, the incidence of a source-based tax on mobile capital income is likely to be shifted substantially to labor in a small open economy, which leaves little argument in favor of such a tax, given that it also distorts the allocation of capital. The extent that the UK or U.S. economy resembles a small open economy in this respect is subject to some dispute, of course, but they surely must be closer now than in the past, and hence the argument for source-

\footnotetext{
${ }^{15}$ See, for example, the statistics presented in Auerbach, Devereux, and Simpson (2010).
} 
based taxation is weaker. Even with the introduction of the ACE reform, though, companies would still have incentives to shift what remains of the corporate tax base from high-tax to lowtax countries (through some combination of shifting actual activities and simply shifting reported earnings), as they do under existing source-based corporate income taxes (and also to a considerable extent under the current hybrid U.S. system). As the Review observes in its summary of the current state of affairs,

There are powerful intellectual arguments against source-based corporate income taxes, and enormous practical problems in their implementation. And yet in spite of these concerns, source-based corporate income taxes - many of which were introduced over a century ago - have survived and continue to raise significant amounts of government revenue in many countries (Mirrlees et al., 2011, p. 432).

In a sense, source-based corporate taxation appears (at least outside the United States) to have won a race between two very slow participants, and the Review offers few cheers for the winner.

As the Review notes, the attractiveness and viability of source-based taxation depends on the extent to which the supernormal returns under its reformed corporate tax would arise from location-specific rents, such as natural resources, rather than those rents that could be relocated to another country. Like many other observers, it sees the declining corporate tax rates around the world as evidence of the increasing importance of mobile rents as sources of corporate tax revenues, with the "race to the bottom" likely to continue without increased tax coordination among countries. Even at the current UK tax rate, the Review notes that introduction of the ACE system would narrow the tax base and reduce revenues, but it cautions against adopting offsetting changes to maintain corporate tax revenues at their prior level:

Our discussion of the tradeoffs in determining the appropriate rate for a source-based corporate tax on economic rents in an open economy setting cautions against this approach. The international trend in corporate tax rates has been downward, and a country that bucks this trend also risks sending a dangerous signal to investors. If a source-based tax on the normal return component of corporate profits is undesirable, and the current UK corporate tax rate is considered more or less appropriate, the implication 
is that less revenue should be raised from the corporate tax (Mirrlees et al., 2011, pp. 449-450).

This is an important lesson for current U.S. policy discussions, which have largely accepted the notion that corporate tax reform should be achieved within a (corporate) revenue-neutral framework. If there is a stronger reason than in the past to reduce the corporate tax rate, or to exempt the normal return to capital from taxation, then it is highly implausible, given the changing economic conditions that make these modifications desirable, that it would be optimal to recover exactly 100 percent of the lost revenue through offsetting changes elsewhere in the corporate tax base, rather than relying in part, say, on a shift to less mobile tax bases at the individual level or among noncorporate entities.

One can learn little directly from the Review about the desirability of strengthening the U.S. residence-based tax system, for it takes source-based taxation as the only serious option of the two. The U.S. and UK economies are different, of course. In particular, the U.S. economy is larger and the government may have market power, so the trade-offs the government faces in the design of its tax system differ from those faced by the United Kingdom with respect to both the tax rate and the tax base. Perhaps location-specific rents are more important in the United States, or the ability of corporations to relocate is smaller. But, again, these are not questions that the Review addresses.

The Review does recognize that the third approach to tax base definition, on the basis of destination, is also potentially available for corporate taxation. This approach, as discussed in the first-volume paper by Auerbach, Devereux, and Simpson (2010), is basically a source-based tax with the addition of border adjustments taking the same form as under a VAT. ${ }^{16}$ The system

\footnotetext{
${ }^{16}$ The border adjustments would apply to sales and purchases, as under a VAT, even though the tax base itself would be narrower as a consequence of excluding wages and salaries. That is, the adjustment for exports would not be based on tax actually paid, but rather solely on the sale price. For example, consider a good sold for export for
} 
envisioned by Auerbach, Devereux, and Simpson, which would adopt cash-flow taxation, i.e., EET, as its method of relieving the tax on the normal rate of return, can also be seen as starting from a subtraction-method VAT (on the corporate sector), with border adjustments already in place, and then allowing a deduction for labor costs. ${ }^{17}$

An advantage of the destination-based approach is that the border adjustments eliminate the incentive for companies to use transfer pricing or other methods to shift earnings to other countries - understatement of the value of exports or overstatement of the cost of imports, both of which would shift the reported source of earnings to another country, would be exactly offset by the resulting change in border adjustments. Indeed, because a destination-based tax would impose no tax at all according to the source of earnings, it would effectively impose a zero tax rate on all domestic source earnings, providing companies an incentive to shift earnings inward, even from low-tax countries that impose a source-based tax. Also, the destination-based approach could be very simple in practice, for it would not be necessary to use border adjustments at all. Instead, one could just ignore cross-border transactions entirely when computing a company's tax base, because the border adjustments would exactly offset the tentative taxes on revenues and deductions for inputs (Auerbach, 2010b). That is, the destinationbased corporate tax would (like a source-based tax) ignore exclusively foreign activities, but could be seen as effectively ignoring cross-border activities as well.

Of course, there are barriers to adopting a destination-based tax, perhaps the most significant being that it might violate World Trade Organization rules, which limit border adjustments to "indirect" taxes like the VAT. While there is no logic whatsoever in making such

$\$ 100$ and produced entirely domestically, i.e., with domestic value added of $\$ 100$. Suppose that this domestic value added includes $\$ 70$ of wages and salaries, so that $\$ 30$ of the value added will have been subject to tax. The border adjustment would still apply to the full $\$ 100$.

17 The President's Advisory Panel on Federal Tax Reform (2005) also laid out such an approach in its "Growth and Investment Tax." 
a distinction between direct and indirect taxes, given that the tax bases, tax rates and the resulting incidence and behavioral effects under the two approaches can be identical, its inclusion in existing international tax rules and treaties cannot simply be assumed away.

Border adjustments, or their equivalent, also raise an issue of the wealth effects arising in transition. For a country with its own currency and a policy of exchange rate flexibility, like the United States or the United Kingdom, the imposition of border adjustments, on their own (that is, as distinct from changes in the tax structure) would likely play out primarily through an exchange rate revaluation, rather than having the export-promoting effects that might hold under a fixed-exchange rate regime or within a common currency area, and which have mistakenly been viewed as an attraction of border adjustments by some in U.S. policy circles. ${ }^{18}$ However, such an exchange rate adjustment would effectively transfer substantial wealth from domestic owners of foreign assets (which would fall in value in the domestic currency) to foreign owners of domestic assets (which would increase in value in the foreign currency). Given the large amounts of cross-border holdings (and it is the gross amounts that matter for the calculation), this is a serious policy issue. Though offsetting transition tax assessments could be contemplated, these would likely be politically difficult to implement in practice; windfalls are simply less salient than the charges that would be needed to offset them. ${ }^{19}$

As the Review notes, the appeal of destination-based taxation may grow over time as the mobility of rents puts further downward pressure on tax rates under existing source-based systems. Presumably, this will also provide time to overcome the irrational restrictions of international agreements.

\footnotetext{
${ }^{18}$ The arguments on this point are reviewed in Auerbach (2008).

${ }^{19}$ One possible compromise, suggested by Bradford (2004) and Carroll and Viard (2012), would be to impose border adjustments only on related-party transactions, where transfer-pricing issues are the most significant. But this would leave the system with other disadvantages of source-based taxation, notably the incentive for companies to shift rent-producing activities to other jurisdictions.
} 
In summary, by proposing adoption of the ACE for corporate equity, the Review sets forward a reform that would reduce various distortions associated with corporate decisions, including in the international context. But, essentially by default, it sees this reform as occurring within the existing source-based tax system, implicitly discarding the alternative of residencebased taxation and viewing destination-based taxation as more of an option for the longer run. Thus, its analysis lies some distance from the current U.S. debate, where strengthening the system of residence-based taxation is still viewed as a serious option.

\section{RATE STRUCTURE AND THE FAMILY UNIT}

There are typically two places in the income distribution where high marginal tax rates are an issue: at the top, where the question is how high rates can be set without discouraging economic activity too much, and at the bottom, where phase-outs of various income support programs are used to limit their cost but can impose very high marginal rates in the phase-out range. The Review devotes attention to both issues.

Since the seminal contribution by Mirrlees (1971), we have understood that high marginal tax rates at the very top of the income distribution may be counterproductive in raising revenue, particularly if marginal rates may be adjusted independently at somewhat lower levels of income. The intuition is that increasing a marginal tax rate at any particular income level raises revenue on all with higher incomes who are subject to the tax, but distorts only the behavior of those at that particular income level. Thus, while raising marginal tax rates near the bottom is most efficient, it also snares many low-income taxpayers. But raising marginal tax rates near the very top raises very little (if any) revenue relative to the distortion imposed, so that even if the cost to taxpayers of the revenue raised is given little (or no) weight in the computation of social welfare, it is not desirable to impose marginal tax rates that are too high. 
As further clarified in the work of Diamond (1998) and Saez (2001), the optimal marginal rate on high-income individuals will depend on three factors: how much weight one gives to the well-being of high-income individuals (-), how responsive their earnings are to marginal tax rates (-), and how thick the upper tail of the income distribution is $(+)$. Since the contribution by Feldstein (1995), we have also understood that, under certain assumptions, the relevant marginal tax rate elasticity is of the tax base itself — taxable income — rather than hours worked or some other narrow measure of labor supply that might be less responsive. Also, if one assigns no social welfare weight at all to the highest income individuals (a close approximation under reasonable inequality aversion), then the optimal tax rate on them will simply be the one that maximizes the tax revenue collected from them.

As shown by Diamond and Saez (2011), a very simple formula applies in this case if incomes in the upper tail follow a Pareto distribution ${ }^{20}$ and the elasticity of taxable income is constant across individuals, in which case the optimal/revenue-maximizing top marginal tax rate is $\tau^{*}=1 /(1+a e)$, where $e$ is the elasticity of taxable income and $a$ is the Pareto distribution parameter (equal to the ratio of average incomes, $z^{m}$, of those above a particular income level, $z^{*}$, divided by the average income above that level, that is, $\left.a=z^{m} /\left(z^{m}-z^{*}\right)\right)$. Diamond and Saez estimate $a=1.5$ and choose $e=.25$ based on their review of the literature, yielding an estimate of $\tau^{*}$ of just under 73 percent. This leads Diamond and Saez to support a substantial increase in

\footnotetext{
${ }^{20}$ Incomes in the upper tail cannot follow a Pareto distribution forever for a finite distribution, so this formula would not hold if the top marginal tax rate were to apply only at the very top, where the standard Mirrlees result of a zero marginal rate would still apply. The analysis here applies under the realistic assumption that the threshold for the top rate is set within the range where the Pareto approximation holds. As Diamond and Saez note, it also would apply for a finite distribution if the top income were a random draw from a Pareto distribution rather than being known with certainty before the tax rates were fixed.
} 
the top U.S. marginal income tax rate, which currently is 35 percent and, even with social insurance taxes and state taxes added, does not approach this value of $\tau^{*}$. $^{21}$

By contrast, the Review expresses concern about the current top rate of the UK income tax, which recently added a 50 percent bracket for those with incomes over $£ 150,000 .^{22}$ Citing an estimate of the parameter $e=.46$ in the Review's first volume by Brewer, Saez, and Shephard (2010), the Review calculates a revenue-maximizing top tax rate of 56 percent, which by the formula above is consistent with a Pareto parameter of $a=1.7$. That is, the Review adopts parameters within a reasonable range of those chosen by Diamond and Saez, with both choices (more responsive behavior and a thinner tailed distribution) contributing to a lower revenuemaximizing tax rate. Given other taxes that apply to top UK earners, the Review's point estimates put the revenue-maximizing tax rate for the individual income tax at 40 percent — the previous top tax rate and well below the current top tax rate, suggesting that the recent adoption of the top tax rate of 50 percent was a revenue-reducing move. ${ }^{23}$

The Review notes the uncertainty associated with this estimate, suggesting a probability of only two-thirds that the revenue-maximizing income tax rate (for which the point estimate, as already discussed above, is 40 percent) falls between 33 percent and 57 percent, even if the

\footnotetext{
${ }^{21}$ Note that only the 2.9 percent tax for the health insurance portion of Medicare, and not the 12.4 percent Old-Age, Survivors, and Disability Insurance (OASDI) tax, will apply at the margin to the majority of individuals in the top income tax bracket, given the current wage ceiling of the OASDI tax (\$110,100 as of 2012). One would also want to take state-level income taxes into account in computing the revenue-maximizing federal income tax rate, because they are effectively on the same base. If one assumes that the federal government wishes to internalize fully the negative revenue externalities that its rate increases cause for the states, then one would simply treat the effective income tax rates of the different taxes as cumulative. Other state taxes, such as sales taxes, would also be affected by changes in the federal income tax rate, although the impact might be smaller because the tax bases are different. For example, some of the income response to higher marginal income tax rates might involve sheltering activity that does not reduce spending on commodities subject to sales tax.

${ }^{22}$ The top rate previously had been 40 percent; this rate still applies for those in the previous top bracket with incomes below $£ 150,000$.

${ }^{23}$ Indeed, the UK Budget released on March 21, 2012 (HM Treasury, 2012) announced that the top rate would be reduced from 50 percent to 45 percent effective April 2013, citing as justification lower than anticipated revenue from the higher rate because "the behavioral response has been larger than expected" and suggesting that the net revenue impact of the higher rate might ultimately be negative (HM Treasury, 2012, p. 31).
} 
historically estimated elasticity still applies. But it also notes that policy must proceed, regardless of uncertainty:

So we do not know with confidence what the revenue-maximizing top tax rate is. But governments do not have the luxury of stopping there: policy must be decided, so, in the absence of compelling evidence, they must take a best guess. The Treasury's best guess is that the $50 \%$ rate will raise some revenue. That is certainly not impossible, but it is certainly uncertain. (Mirrlees et al., 2011, p. 110)

It is disturbing to contemplate the degree of uncertainty regarding what the top income tax rate should be, in light of the very charged nature of this issue in policy circles. Small variations of two key parameters move us from the Diamond-Saez estimate of 73 percent to the Review's 56 percent for the revenue-maximizing tax rate, with both calculations otherwise making the same assumptions and adopting the same methodology. Yet, for the last several years, the very fierce U.S. tax policy debate has been whether the top federal rate should be allowed to increase by less than 5 percentage points, from 35 percent to 39.6 percent, the latter being the top income tax rate that would apply if the Bush tax cuts expired. The lesson is not necessarily that the policy argument is over something trivial, but perhaps that there may be something missing from our analysis.

For example, in taking the objective to be finding the revenue-maximizing tax rate, one is assigning zero weight to the welfare of those in the top bracket. Diamond and Saez note, however, that reasonable deviations in this assumption do not have a major impact on the outcome, as a standard social welfare function is likely to assign much lower weight to those at the top than those of average incomes. But this implies that there is little lost if we adopt a policy of increased marginal tax rates that ends up losing a small amount of revenue. One suspects that this is not a view held widely by policy makers, and it is hard to imagine an economist testifying before a Congressional Committee in favor of a marginal tax rate increase because it is more 
likely than not to raise revenue, even though the net revenue gain will be small relative to the gross revenue increase (i.e., the increase in revenue if there were no behavioral responses).

The Review suggests that concern over longer-term behavioral effects might also reduce the attractiveness of increasing the top marginal rate. Presumably, these would involve such things as educational and professional choices, as well as, possibly, shifts in norms regarding such things as how hard to work and when to retire. It also notes that base-broadening among upper income individuals can be a complementary activity, for it not only raises revenue from the same group, but also reduces their ability to shift income to avoid tax in response to marginal tax rate increases, and thus serves to justify higher marginal rates than would be desirable without base reform.

At the bottom of the income distribution, the UK's individual-based system of income taxation comes up against its family-based system of benefits. The issue of joint versus individual taxation is of course familiar to those in the United States from our ongoing debate about marriage penalties and bonuses, where we confront the well-known proposition that it is impossible to achieve simultaneously the three potential objectives of marriage neutrality (same overall tax on two individuals whether or not they are married), equity among married couples with the same overall income (same overall tax regardless of the division of their incomes) and progressivity (increasing average tax rates for those with higher incomes). Mandatory joint filing for couples (which is essentially the U.S. approach, given that the "married filing separately" option is rarely an attractive one) satisfies the last two objectives, mandatory individual filing satisfies the first and the third, and proportional income taxation satisfies the first two.

The United States is believed to be constrained (politically, if not legally) to its current system of joint taxation due to state community property laws that effectuate income splitting 
even in the case of individual filing. ${ }^{24}$ But, for the United Kingdom, the use of individual taxation creates potential inconsistencies with other elements of the tax-transfer system. This was already mentioned in the context of inheritance taxation, and it arises again when one considers the system of benefits for lower income individuals, where assessments of ability to pay are family-based.

Here, the Review's objective of having a simple and transparent tax system that avoids unintended incentives confronts a complicated reality. Having some elements of the system that are family-based and others that are individual-based can have undesired effects. For example, a poor couple with unequal incomes might pay higher tax but receive the same benefits as one with equal incomes. The Review deals with this issue in several ways. First, it suggests the use of sequential rather than simultaneous income assessments for tax and benefit purposes. That is, the first couple in the example just given would have higher taxes and hence lower after-tax income used for benefit-assessment purposes. Second, the Review suggests the reform and integration of different benefit systems, which can at least eliminate undesirable interactions among benefit programs. Finally, it points out that in practice the objectives of taxes and benefits differ. While the taxpaying and benefit-receiving populations overlap, they are fairly distinct. For example, around a quarter of UK households pay no income tax, a fraction that may seem large but is substantially smaller than the 47 percent recently estimated for the United States (Williams, 2009); means-tested benefits generally are irrelevant for those with higher incomes who account for the bulk of tax payments. Indeed, the declining "jointness" of the tax-transfer system as incomes rise may be seen as consistent with optimal tax considerations, which suggest that the

\footnotetext{
${ }^{24}$ One can imagine that changes in marriage rates and the definition of marriage might eventually alter this landscape, but only over the longer run.
} 
interdependence of income tax rates should decline as incomes rise and equity among couples becomes a less important consideration (Kleven, Kreiner, and Saez, 2009).

In thinking about taxation of the family, one lesson for the United States is that even with joint assessment for both taxes and benefits, there are still instruments available for varying the extent to which marginal tax rates interact. For example, between 1982 and 1986, the U.S. income tax included a second-earner deduction for two-earner households, equal to 10 percent of the second earner's earnings up to a maximum deduction of $\$ 3,000$, which effectively lowered the impact of the primary earner's income on the second-earner's marginal tax rate for moderate levels of earnings, and also encouraged the participation of second earners in the labor market. That provision was repealed as part of the Tax Reform Act of 1986, perhaps in the name of simplicity, but it was really just a modification of the rate schedule and could have been expressed in that way. ${ }^{25}$

Finally, as concerns the incentive effects of explicit and implicit marginal tax rates, the Review's analysis focuses on two dimensions with much greater clarity than is typical of realistic policy analysis, which provides a payoff in terms of its ability to analyze particular reforms. First, it considers the incentive effects at both extensive and intensive margins, providing separate figures that plot, respectively, participation tax rates and effective marginal tax rates. These come into play when the Review considers the effects of particular reforms, which can have distinct effects at the two margins. Second, life-cycle considerations are taken into account in a concrete way, for example in a proposed reform that would increase the child tax credit (and also the tax rates implicit in the phase-out range) for parents of younger children while reducing the credit and phase-out severity for parents of older children. The rationale is that labor supply

\footnotetext{
${ }^{25}$ The 1986 Act also flattened the marginal rate schedule and hence would have lowered the value of the secondearner deduction.
} 
is less responsive for parents of younger children, so that the higher marginal tax rates in the phase-out range would be less damaging, while at the same time there would be little net change in the distribution of tax payments over the life cycle of the child.

While this type of subtle policy shift makes sense, one should keep in mind that conditioning taxes on a child's age leads to complexity in the tax system, especially because the relevant age might be different for different provisions. For example, children remain dependents after they no longer require paid childcare. Indeed, the variation in the definition of a child for different provisions in the tax code has been a recent target of policy reform in the United States. ${ }^{26}$

\section{CONCLUSIONS}

As the preceding discussion indicates, the Mirrlees Review represents an unusual blend of "best practice" application of economic theory and evidence to realistic policy design; it lays out policy proposals with sufficient justification and specificity that they go well beyond a statement of principles for reform. While the realism doesn't necessarily extend to the question of what is politically possible (which might have led to a very short volume if based on the current U.S. political climate), the Review does incorporate some judgments as to feasibility, such as retaining source-based corporate taxation and eschewing cash-flow taxes in favor of the RRA approach, as well as other choices not mentioned above, including side-stepping the potentially controversial issue of whether further tagging of benefits based on individual characteristics might be desirable, and leaving for another day the very important question of whether the existing level of revenue is appropriate, given the current government spending trajectory.

\footnotetext{
${ }^{26}$ The Working Families Tax Relief Act of 2004 set a uniform definition of a qualifying child, beginning in 2005, for the Dependency Exemption, the Child Credit, the Earned Income Credit, the Dependent Care Credit, and Headof-Household Filing Status.
} 
The reforms the Review puts forward are intended to be revenue-neutral, and the word "deficit" does not appear until its concluding chapter, where the complementarity of tax reform and increased revenue is noted: "As many countries look to address fiscal deficits by raising more money through their tax systems, the importance of getting the structure of taxes right can only increase" (Mirrlees et al., 2011, p. 470). From a U.S. perspective, this is perhaps the Review's most important lesson. 


\section{ACKNOWLEDGEMENTS}

I am grateful to Richard Blundell, Peter Diamond, Michael Graetz, Jim Poterba,

Emmanuel Saez, Dan Shaviro, and participants in seminars at Harvard and NYU Law Schools

for comments on an earlier draft.

\section{REFERENCES}

Aiyagari, S. Rao, 1995. "Optimal Capital Income Taxation with Incomplete Markets, Borrowing Constraints, and Constant Discounting.” Journal of Political Economy 103 (6), 1158-1175.

Atkinson, Anthony B., and Joseph E. Stiglitz, 1976. "The Design of Tax Structure: Direct versus Indirect Taxation." Journal of Public Economics 6 (1-2), 55-75.

Auerbach, Alan J., 1996. "Tax Reform, Capital Allocation, Efficiency and Growth." In Aaron, Henry J., and William G. Gale (eds.), Economic Effects of Fundamental Tax Reform, 29-81. Brookings Institution, Washington, DC.

Auerbach, Alan J., 2008. "The Choice between Income and Consumption Taxes: A Primer." In Auerbach, Alan J., and Daniel N. Shaviro (eds.), Institutional Foundations of Public Finance: Economic and Legal Perspectives, 13-46. Harvard University Press, Cambridge, MA.

Auerbach, Alan J., 2010a. "Public Finance in Practice and Theory." CESifo Economic Studies 56 (1), 1-20.

Auerbach, Alan J., 2010b. “A Modern Corporate Tax.” Center for American Progress/Hamilton Project. Washington, DC.

Auerbach, Alan J., 2011. "Consumption Tax Options for California.” Public Policy Institute of California, San Francisco, CA.

Auerbach, Alan J., Michael P. Devereux, and Helen Simpson, 2010. "Taxing Corporate Income." In Mirrlees, James, Stuart Adam, Timothy Besley, Richard Blundell, Stephen Bond, Robert Chote, Malcolm Gammie, Paul Johnson, Gareth Myles, and James Poterba (eds.), Dimensions of Tax Design, 837-893. Oxford University Press, Oxford, UK.

Auerbach, Alan J., and Laurence J. Kotlikoff, 1987. Dynamic Fiscal Policy. Cambridge University Press, Cambridge, UK.

Banks, James, and Peter Diamond, 2010. "The Base for Direct Taxation.” In Mirrlees, James, Stuart Adam, Timothy Besley, Richard Blundell, Stephen Bond, Robert Chote, Malcolm Gammie, Paul Johnson, Gareth Myles, and James Poterba (eds.), Dimensions of Tax Design, 548-648. Oxford University Press, Oxford, UK. 
Batchelder, Lily, 2007. "Taxing Privilege More Effectively: Replacing the Estate Tax with an Inheritance Tax." Hamilton Project Discussion Paper 2007-07. The Hamilton Project, Brookings Institution, Washington, DC.

Bradford, David F., 2004. "The X-Tax in the World Economy." NBER Working Paper No. 10676. National Bureau of Economic Research, Cambridge, MA.

Brewer, Mike, Emmanuel Saez, and Andrew Shephard, 2010. "Means Testing and Tax Rates on Earnings." In Mirrlees, James, Stuart Adam, Timothy Besley, Richard Blundell, Stephen Bond, Robert Chote, Malcolm Gammie, Paul Johnson, Gareth Myles, and James Poterba (eds.), Dimensions of Tax Design, 90-173. Oxford University Press, Oxford, UK.

Burman, Leonard E., Julianna Koch, Greg Leiserson, and Jeffrey Rohaly, 2008. "The Individual Alternative Minimum Tax (AMT): 12 Facts and Projections.” Tax Policy Center, Urban Institute and Brookings Institution, Washington, DC.

Carroll, Robert, and Alan D. Viard, 2012. Progressive Consumption Taxation: The X-Tax Revisited. AEI Press, Washington, DC.

Crawford, Claire, and Judith Freedman, 2010. "Small Business Taxation." In Mirrlees, James, Stuart Adam, Timothy Besley, Richard Blundell, Stephen Bond, Robert Chote, Malcolm Gammie, Paul Johnson, Gareth Myles, and James Poterba (eds.), Dimensions of Tax Design, 1028-1099. Oxford University Press, Oxford, UK.

Diamond, Peter, 1998. "Optimal Income Taxation: An Example with a U-Shaped Pattern of Optimal Marginal Tax Rates.” American Economic Review 88 (1), 83-95.

Diamond, Peter, and Emmanuel Saez, 2011. "The Case for a Progressive Tax: From Basic Research to Policy Recommendations.” Journal of Economic Perspectives 25 (4), 165-190.

Erosa, Andres, and Martin Gervais, 2002. "Optimal Taxation in Life-Cycle Economies." Journal of Economic Theory 105 (2), 338-69.

Feldstein, Martin, 1995. "The Effect of Marginal Tax Rates on Taxable Income: A Panel Study of the 1986 Tax Reform Act." Journal of Political Economy 103 (3), 551-572.

Fisher, Irving, 1939. “The Double Taxation of Savings.” American Economic Review 29 (1), 1633.

Golosov, Mikhail, Narayana Kocherlakota, and Aleh Tsyvinski, 2003. "Optimal Indirect and Capital Taxation." Review of Economic Studies 70 (3), 569-587.

Griffith, Rachel, James Hines, and Peter Birch Sørensen, 2010. "International Capital Taxation." In Mirrlees, James, Stuart Adam,Timothy Besley, Richard Blundell, Stephen Bond, Robert Chote, Malcolm Gammie, Paul Johnson, Gareth Myles, and James Poterba (eds.), Dimensions of Tax Design, 914-996. Oxford University Press, Oxford, UK. 
HM Treasury, 2012. Budget 2012. HC 1853. HM Treasury, London, UK.

Institute for Fiscal Studies, 1978. The Structure and Reform of Direct Taxation. Allen and Unwin, London, UK.

Institute for Fiscal Studies Capital Taxes Group, 1991. Equity for Companies: A Corporation Tax for the 1990s. Commentary 26. Institute for Fiscal Studies, London, UK.

Kaldor, Nicholas, 1955. An Expenditure Tax. Allen and Unwin, London, UK.

Kleven, Henrik Jacobsen, Claus Thustrup Kreiner, and Emmanuel Saez, 2009. "The Optimal Income Taxation of Couples." Econometrica 77 (2), 537-560.

Mirrlees, James A., 1971. "An Exploration in the Theory of Optimum Income Taxation." Review of Economic Studies 38 (2), 175-208.

Mirrlees, James, Stuart Adam, Timothy Besley, Richard Blundell, Stephen Bond, Robert Chote, Malcolm Gammie, Paul Johnson, Gareth Myles, and James Poterba (eds.), 2010. Dimensions of Tax Design: The Mirrlees Review. Oxford University Press, Oxford, UK.

Mirrlees, James, Stuart Adam, Timothy Besley, Richard Blundell, Stephen Bond, Robert Chote, Malcolm Gammie, Paul Johnson, Gareth Myles, and James Poterba, 2011. Tax by Design: The Mirrlees Review. Oxford University Press, Oxford, UK.

Pechman, Joseph A., 1987. Federal Tax Policy. Brookings Institution Press, Washington, DC.

President's Advisory Panel on Federal Tax Reform, 2005. Simple, Fair, and Pro-Growth: Proposals to Fix America's Tax System. U.S. Government Printing Office, Washington, DC.

President's Economic Recovery Advisory Board, 2010. The Report on Tax Reform Options: Simplification, Compliance, and Corporate Taxation. U.S. Government Printing Office, Washington, DC.

Saez, Emmanuel, 2001. "Using Elasticities to Derive Optimal Income Tax Rates." Review of Economic Studies 68 (1), 205-229.

Saez, Emmanuel, 2002. "The Desirability of Commodity Taxation under Non-Linear Income Taxation and Heterogeneous Tastes." Journal of Public Economics 83 (2), 217-230.

Saez, Emmanuel, 2006. "Income Concentration in a Historical and International Perspective." In Auerbach, Alan J., David Card, and John M. Quigley (eds.), Public Policy and the Income Distribution, 221-258. Russell Sage Foundation, New York, NY.

Sørensen, Peter Birch (ed.), 1998. Tax Policy in the Nordic Countries. Palgrave Macmillan, London, UK. 
U.S. Department of the Treasury, 1977. Blueprints for Basic Tax Reform. U.S. Department of Treasury, Washington, DC.

U.S. Department of the Treasury, 2012. The President's Framework for Business Tax Reform. The White House and U.S. Department of the Treasury, Washington, DC.

U.S. Office of Management and Budget, 2012. The President's Budget for Fiscal Year 2013. The White House, Washington, DC.

Warren, Alvin C., Jr., 1995. "The Proposal for an 'Unlimited Savings Allowance." Tax Notes 68 (August 28), 1103-1108.

Warren, Alvin C., Jr., 1996. "How Much Capital Income Taxed Under an Income Tax Would Be Exempt Under a Cash-Flow Tax?” Tax Law Review 52 (1), 1-16.

Williams, Roberton, 2009. “Who Pays No Income Tax?” Tax Notes 123 (June 29), 1583. 